\title{
The Role of Parents on the Character Education of Kindergarten Children Aged 5-6 Years in Bima
}

\author{
Joko Ansari Setiawan ${ }^{1, *}$, Suparno $^{2}$, Chuduriah Sahabuddin $^{3}$, Tasrif $^{4}$, Syahrul Ramadhan $^{4}$ \\ ${ }^{1}$ Early Childhood Education Program, Universitas Negeri Yogyakarta, Indonesia \\ ${ }^{2}$ Lecturer of Post Graduate Program, Universitas Negeri Yogyakarta, Indonesia \\ ${ }^{3}$ Universitas Al Asyariah, Mandar, Indonesia \\ ${ }^{4}$ Doctoral Program, Universitas Negeri Yogyakarta, Indonesia
}

Received November 5, 2019; Revised January 8, 2020; Accepted February 7, 2020

Copyright $\odot 2020$ by authors, all rights reserved. Authors agree that this article remains permanently open access under the terms of the Creative Commons Attribution License 4.0 International License

\begin{abstract}
This study aims to examine the effect and the role of (1) parents' attention on early childhood character education; (2) parents' affection on the early childhood character education; (3) security on the early childhood character education; and (4) parents' attention, parents' affection, and security on the early childhood character education silmultaneously. The method of this research was ex-post facto research. The populations in this study were parents and children in kindergarten of Bima city. Samples from the population were taken from 2 sub-districts namely the Rasa Na'e Barat sub-district and Punda sub-district, which consist of 157 Parents. Instruments used in this research were observations and questionnaires. Meanwhile the data analysis was carried out by using certain techniques which was Inferential Statistics with multiple regression analysis. The result of this study showed that the role of parents' attention on early childhood character education has a significant effect of 0.570 and parents' affection love also has a significant effect on character education of early childhood actually as much as 0.572 . While the analysis on the effect of security on character education for early childhood is 0.453 . Multiple regression tests show that there was a very large effect from parents' attention, affection and safety in early childhood character education which was 30,618 . These results proved that the role of attention, affection, and security given by parents directly affects the character education of early childhood.
\end{abstract}

Keywords Parents, Character Education

\section{Introduction}

The environment is a place where children grow and taproot so that the environment can play a role in shaping the character of early childhood education. For most children, the environment affects their development, which will then be continued in schools and communities. The family becomes the first school in learning where parents become teachers or role models in charge of educating and guiding children [1,2]. Parents are the first educators for children who determine the success of children in long-term education and the values taught in the strength of children outside, that is in school and community with the school in a joint effort to meet the needs and shape the development of children (Lickona) [3]. Therefore, parents need to know that they can make a big difference in their children's lives by ensuring that they know the facts.

Parents have an important role in educating and nurturing their children to be individuals who are good, intelligent, and skilled in their daily lives. The role of parents in children's education is to provide basic education, attitudes, and basic skills, such as religious education, ethics, courtesy, aesthetics, compassion, security, and teaching behavioral that is consistent with what is taught in the school $[4,5,6]$. The role of parents is to give their children attention, affection, and security in order to make good children in the future. Therefore, with the involvement and attention of parents can have a positive impact in increasing motivation and shaping good values of children.

Naming and fostering character education must be carried out from an early age where in this case it is strongly influenced by the contribution and role of parents. Character building is the values of human behavior related to the one true God, himself, fellow human beings, the environment, and nationality manifested in thoughts, attitudes, feelings, words, and deeds $[7,8]$. Erikson added in Noor [5] that coaching the character of children is the 
early depiction of humans, where policies develop slowly and surely. While [3] it is said that parents act as caregivers, examples and coaching, which treats children through feelings of love and respect for good examples, supports pro social behavior, and corrects wrong actions. Therefore, education in the family is very important so that it is the main pillar to shape the character of early childhood and hopefully children are accustomed to doing positive things. These positive things will become part of the child's personality that has character values.

The involvement of parents in early childhood education is not seen from their children in educational institutions, but parents in this case are directly involved in education for their children. There are several forms of parental involvement in early childhood education. According to Moles in Olsen and Fuller [9], it is stated that family involvement in children's education takes many forms and levels both at school and outside of school. School-oriented involvement is the involvement of parents with schools such as attending meetings and also participating in school activities. Home-oriented parent involvement is the involvement of parents who are in the home environment, such as making children talk about what they are doing at school, accompanying children to do assignments, reading with children or providing a place for children to read or to pursue school glory.

The type of parent involvement in children's education has the same type of basic involvement as that carried out at home-involvement and also the involvement that is carried out at school, but many development activities refer to these two types of involvement, namely parental participation at school and at home and parent participation in the community. Apart from those described above, there is a general type of description of parental involvement in children's education by Christenson, Reschly and Wylie [10]. Descriptions of the general types of parental involvement in education are divided into four types: parental participation in schools, parental involvement at home, parental involvement in schools and learning and the last participation of parents, in Community Activities.

Parental involvement in children's education does have many benefits, but behind them, parents have a more difficult risk to be directly involved in early childhood education, one of which appears in old age and also for those who have a low economic level. One of the problems affecting schools is the problem of family finances and children's environment [11].

Financial problems or low economic levels in a child's family can affect children's education. The environment of children that have financial problems cannot help families so that children cannot get a good quality school. In addition, the involvement of parents with low economic levels can be interrupted. Parents with low economic level pay more attention to work to help family finances and also pay school fees so they do not have time to attend activities at school.

Parents' involvement in children's schools will have a positive impact on children, such as achieving higher grades, children's presence in school increases and also the formation of behavior and habits in children is better (Henderson and Bela in [12]. Epstein and Dauber [13] cited several positive effects of parental involvement in education, both in academic and non-academic outcomes, children with parents involved in children's education, would have better academic value.

The positive effect of parental involvement in education the non-academic thing is that children are easier to pass the transition to new schools, increase the presence of children in school and also children have better behavior and can reduce children's bad behavior Parents have different contributions in education their children. Therefore, parental involvement in early childhood education is the participation of parents in the education of their children, whether in the home in the form of parenting, discussing with children, and support of home and learning relating to communication with The school, parental participation in school activities, and joining the parents ' community.

Based on observations conducted by researchers in one of the kindergartens in the City of Bima, character education has been carried out, but in its application has not been optimal. It is seen from observations that have been made. In the case of Discipline, five (5) out of the eight (8) Group B students have not yet wanted to return the item where they took it and in terms of independence, six out of the eight of group B were still accompanied by their parents when they were at school, where some of them waiting in class or outside of class.

Unlike other kindergartens, Al Amin Kindergarten for example, has students with different characters. Al Amin Bima Kindergarten is an Islamic-based school that makes character as one of the flagship of this school. As Al Amin Bima Kindergarten has habits like; School with no waiting for parents, leaving school on time, children are introduced to the attitude of manners and courtesy with always smiling. Phrases like apologize, ask for help and thank you is also often spoken by children. Educators applying that characterize the school is the regular morning activities in which it contains the planting of a variety of character values that are useful for children.

Al Amin Bima Kindergarten is an institution that implements character education which is one of the more values possessed by this school when compared to other schools. This can be seen from the vision of TK Al Amin in Bima city that the school aims to form healthy, smart, cheerful, playful and fearful children of Allah SWT. Therefore, researcher wanted to know the learning process at $\mathrm{Al}$ Amin Kindergarten, Bima City. So, the purpose of this study is to find out the effect and impact of (1) the role of parents based on parents' attention; (2) 
The role of parents based on parents' affection; and (3) the role of parents based on the sense of security in shaping the values of early childhood character in the City of Bima.

\section{Methods}

The type of this study was experimental research with the ex-post facto type. The aims was to find out the effect between the two variables. Ex-post facto design is a study conducted to examine events that have occurred and then repose to find out the factors that can cause these events [14]. This study contains three independent variables and one dependent variable. The independent variables in this study are parents' attention (X1), parental love (X2), and child safety (X3), while the dependent variable is the child's character education (Y).

The population in this study refers to several parents who have children in one of the kindergartens in Bima, West Nusa Tenggara. This population is the total number of population to be studied while the research sample is part of the total characteristics possessed by the population. For more details, some kindergartens that are used as places and research samples can be seen in the table below.

Table 1. Research samples

\begin{tabular}{|c|c|c|}
\hline No & School & Parents \\
\hline 1 & TK Al Amin & 22 \\
\hline 2 & TK Al Hikmah & 28 \\
\hline 3 & TK Yaa Bunaya & 25 \\
\hline 4 & RA Perwanida 1 & 31 \\
\hline 5 & TK Kartika & 24 \\
\hline 6 & TK Al Jannah & 27 \\
\hline \multicolumn{2}{|c}{} \\
\hline
\end{tabular}

Instruments which were used in this study that aim to collect data on the role of parents in early childhood character education are observations and polls/questionnaires using the Likert scale. Likert scale was used to measure the level of parents' roles with the total grain/ about 20 questions and statements. The researcher asked several questions and statements to the respondent where they also are provided the choice of answers: Never (TP); Sometimes (KK); Often (SR); and always (SL) with weights: 1, 2, 3, 4. The parents' role instrument in early childhood education process is arranged in questionnaires consisting of questions and statements. While the children's educational instruments are arranged in the form of observations consisting of questions and statements that come with four answer options. Each question consists of four answers options which are (1) very good developing/BSB; (2) Not yet
developed/BB; (3) Start growing/MB; and (4) developing as expected/BSH. Observation instruments can be done by observing the process of learning to teach children who take place in the classroom.

After the instrument is compiled, then it was consulted to the supervisor and followed by a validity test carried out by experts (Experts / Judgement). The data analysis technique in this study was done by using regression analyses between independent variables and dependent variables. The purpose of this analysis is to seek partial effect and jointly, i.e. the effect of $\mathrm{X} 1$ on $\mathrm{Y}$, the effect of $\mathrm{X} 2$ on $\mathrm{Y}$ and the effect of $\mathrm{X} 3$ on $\mathrm{Y}$.

\section{Results}

Based on the results of the initial analysis (prerequisite tests), the data were declared to be eligible for analysis by parametric statistical methods. Calculations can be done by using the computer program SPSS 19.0 for Windows.

The results of calculations in correlation (R) and multiple regression $\mathrm{F}$ tests to test the effect of the variables of attention (X1), affection (X2), and Sense of security (X3) together on the character Education (Y) are shown in table 2 below:

Table 2. Joint Testing

\begin{tabular}{|c|c|c|c|c|}
\hline $\mathrm{R}$ & R square & F count & Sig & Information \\
\hline 0,615 & 0,382 & 31,558 & 0,000 & Significant \\
\hline
\end{tabular}

Based on table 2, R2 is 0.382 which means that the variables of attention (X1), affection (X2), and Security (X3) jointly affect the character education (Y) by $38.2 \%$. There are other variables not examined that affect character education $(\mathrm{Y})$ by $61.8 \%$.

$\mathrm{F}$ count $=31,558$ with $<\alpha(0,000<0,05)$ sig means that the variables of attention (X1), affection (X2), and security (X3) jointly significantly affect on character education (Y).

1) The calculation of the effect of attention (X1), affection (X2), and security (X3) separately on character education $(\mathrm{Y})$

The results of the T-Test calculation on multiple regression to test the effect of the variables of attention (X1), affection (X2), and security (X3) separately on character education $(\mathrm{Y})$ can be seen in table 3 below:

Table 3. Separately Testing

\begin{tabular}{|c|c|c|c|c|}
\hline Variables & Coefficient & T count & Sig & Description \\
\hline Constanta & 30,618 & & & \\
\hline attention (X1) & 0,570 & 2,953 & 0,004 & Significant \\
\hline affection (X2) & 0,572 & 3,332 & 0,001 & Significant \\
\hline $\begin{array}{c}\text { a sense of } \\
\text { security (X3) }\end{array}$ & 0,453 & 2,402 & 0,018 & Significant \\
\hline
\end{tabular}

Based on table 3 then the double regression equation is 
$\mathrm{Y}^{\prime}=30.618+0.570 \mathrm{X} 1+0.572 \mathrm{X} 2+0.453 \mathrm{X} 3$. Based on multiple regression equations, they can be interpreted as follows:

- Constants 30.618 means that if the variable's attention score (X1), affection (X2), and security $(\mathrm{X} 3)=0$, then the character education variable score will be positive by 30.618 .

- The attention variable regression coefficient (X1) of 0.570 means that any increment or increased attention variable score (X1) by 1 , there will be an increase in the character education variable score of 0.570 assuming other variable scores are fixed.

- The affection variable regression coefficient (X2) of 0.572 means that any added or improved variable score of affection (X2) by 1, then there will be an increase in character education variable scores of 0.572 assuming other variable scores are fixed.

- The sense of security variable regression coefficient (X3) of 0.453 means that any addition or increase in the variable score sense of security (X3) by 1, there will be an increase in the character education variable score of 0.453 assuming other variable scores are fixed.

Table 3 indicates the attention variable (X1) obtained by sig $<\alpha(0.004<0.05)$ means variable attention $(\mathrm{X} 1)$ significantly affects character education. Regression coefficient ( 0.570$)$ of positive means the higher the score (the better) the attention then the higher the score (the better) the character education, the lower the score (the better) the attention then the lower the score (the better) the education Character.

Table 3 shows a variable of affection (X2) acquired sig $<\alpha(0.001<0.05)$ means that variable affection $(\mathrm{X} 2)$ significantly affects character education. Regression coefficient $(0.572)$ positive means the higher the score (the better) the affection then the higher the score (the better) the character education, the lower the score (the less good) the affection then the lower the score (the less good) character education.

Table 3 shows the security (X3) variable a sig $<\alpha$ $(0.018<0.05)$ means that sense of security (X3) significantly affects character education. Regression coefficient $(0.453)$ positive means the higher the score (the better) the sense of security then the higher the score (the better) the character education, the lower the score (the less good) the sense of security then the lower the score (the better) the character education.

\section{Discussion}

Based on the results of the analysis of parental attention (X1), it was found that there was a significant effect of parents ' attention on the character education of early childhood in the Bima city. The results of this study show that if parents' attention is getting higher makes the children's character education is higher as well. Conversely, if parents' attention is low or decreased, then the child's education will be low or decreased as well.

The results of the analysis are similar to the results of the study conducted by Ahmadi [15] which stated that the parents' attention has an effect for children to face their learning process so that parents need to pay attention to what is needed and which must be filled by them to support their children's learning activities.
a) Healthy physical condition
b) Discipline, obey, and follow the learning plan.
c) Having a study room or study place suitable with learning activities.
d) Prepare school equipment properly before the children leave for school.
e) Have a well-prepared in-house study schedule.
f) Can focus and concentrate on learning process.
g) Having confidence in self-ability.

Shaleh [16] defines the manifestation of parents' attention to children so that for children to be successful in the learning process, parents need to pay attention to children's education, interests and needs. Parents' attention in children's education, for example, organizes learning time, completes learning equipment, supervises children while studying, knows the child's learning progress, sees difficulties in children's learning, and helps solve problems.

Based on these two opinions it can be concluded that the manifestation of parental attention can be done by meeting the child's needs for learning. Children's needs that need to be met as a form of attention of parents is to pay attention to children's health, supervise children's learning activities, create a comfortable learning atmosphere, meet children's learning needs and provide guidance for learning and give rewards and punishment.

The second hypothesis results a positive and significant effect of parents' affection on character education (X2) in the City of Bima which is collectively said to be a very good category. This means that the affection of parents who are actively involved in the process of early childhood character education has a positive and significant influence on their character education. However, there are still some parents who are less involved because of lack of knowledge.

The results of this study proved that the higher the affection of parents in the process of character education, the higher the development of children's character education, if the parents ' affection is less maximized or low, then the development of early childhood education will be lower or decreased as well. But the results of this research show that parents ' affection in providing character education can make an effective contribution to the education of early childhood characters.

Based on these explanations, it can be concluded that 
parenting towards early childhood can make a positive or significant contribution to the character education of early childhood in the City of Bima.

Morrison [17] states that safety and security play an important role in the lives of early childhood, creating a safe classroom and school environment where children will feel safe going through their routine. Security is a dimension in relationships that develops because repeated interactions show a sense of preparedness, sensitivity, and responsiveness. Lestari [20] explains the sense of security in the playing environment and others would encourage children to dare to explore which would be beneficial for the development of competencies.

Unlike the above opinion, Nolte and Harris [21] explain that children develop themselves gradually over many years, because parents give children the opportunity to test their skills and abilities. In order for children to grow with a sense of security, parents must give children enough time and space to experiment, learn for themselves, or even fail, but are ready to give them support, guide, and shape the child throughout their journey.

Noor [5] said that the role of parents in children's education is to provide basic education, attitudes, and basic skills, such as religious education, ethics, courtesy, aesthetics, compassion, security, and teach behavioral values in accordance with taught in school. This is in line with Ikhsanudin \& Hidayati [22] which says that the role of parents is one way to provide basic education, attitudes and character, and basic skills such as religious education, ethics, manners, aesthetics, love, safety, security, the basics of obeying regulations, and fostering good habits and discipline. In a family environment, a boy can know the values and norms of life. A person's behavior in a community is a reflection of his family

According to Baharuddin [6] parents have an important role in the family, that is to educate and nurture their children in order to make them become an individual who has good character, personality, intelligent, and skilled so they are able to carry out their duties in the future and tot be a burden to others.

Parents play an important role in instilling the basic foundation to children in various aspects of the world and the here after. Family is the first school in learning where the parents are the teachers or role model in charge of educating and guiding the child. Dwiningrum [23] said that parents have involvement in education which has positive effect in increasing student motivation. Parents have an important role in the education of their children.

The results of the assessment, whether the outcome of learning or knowing the relationship between variables, will help design the right learning to be applied in learning $[24,25]$. The results of a descriptive analysis of the effect of parents' attention, parents' affection and a sense of security on the character education of early childhood in Bima shows that it is classified very well. It is supported by the results of third hypothesis test which found out that there was a positive and significant effect between the parents' attention, affection and a sense of security in the process of character education in children aged 5-6 years. Besides this is also evidenced by the contribution of parents' attention, affection and a sense of security to the character education of early childhood which is $38.2 \%$. After being tested together, it also has a significant effect. The test was continued by carrying out the a partial influence on character education.

\section{Conclusions}

Based on the results of research and discussion on the role of parents on character education in Bima City above, it can be concluded that (1) there is a significant effect of parents' attention, parents' affection and security on the education of early childhood characters; (2) There is a significant effect of parents' attention on the education of early childhood characters; (3) There is a significant effect of the parents' affection on the education of early childhood characters; and (4) there is a significant effect of the security given by parent on early childhood education.

\section{REFERENCES}

[1] Sofyan, H., \& Anggereini, E. (2019). Developing the reference books of center, area and group learning models based on environment and thematic in early childhood education Universal Journal of Educational Research, 7(10), 2208-2213. doi: 10.13189/ujer.2019.071019.

[2] Sofyan, H., Anggereini, E., \& Saadiah, J. (2019). Development of E-modules based on local wisdom in central learning model at kindergartens in jambi city. European Journal of Educational Research, 8(4), 1137-1143. doi: 10.12973/eu-jer.8.4.1139

[3] Lickona, T.: 'Pendidikan Karakter: Panduan lengkap mendidik siswa menjadi pintar dan baik' (Nusa Media, 2013. 2013)

[4] Jamal, Z.I.D.L., and Idris, H.Z.: 'Pengantar pendidikan' (Grasindo, 2011. 2011)

[5] Noor, R.M.: 'Mengembangkan karakter anak secara efektif di sekolah dan di rumah' (Pustaka Insani Madani, 2012. 2012)

[6] Baharuddin, H.: 'Pendidikan dan Psikologi Perkembangan' (Ar-Ruzz Media, 2014. 2014)

[7] Fadlillah, M., and Khorida, L.M.: 'Pendidikan karakter anak usia dini' (Ar-Ruzz Media, 2013. 2013)

[8] Kurniawan, S.: 'Pendidikan Karakter' (Ar-Ruzz Media, 2013. 2013)

[9] Olsen, G.W., and Fuller, M.L.: 'Home and school relations: 
Teachers and parents working together' (Publishing Library of Congress Cataloging Data, 2011.2011)

[10] Christenson, S.L., Reschly, A.L., and Wylie, C.: 'Handbook of research on student engagement' (Springer Science \& Business Media, 2012. 2012)

[11] McNergney, R.F., and McNergney, J.M.: 'Foundations of education: The challenge of professional practice' (Allyn \& Bacon, 2004. 2004)

[12] Brewer, J.A.: 'Introduction to early childhood education: Preschool through primary grades' (Allyn \& Bacon 2014. 2014)

[13] Epstein, J.L., and Dauber, S.L.: 'School programs and teacher practices of parent involvement in inner-city elementary and middle schools', The elementary school journal, 1991, 91, (3), pp. 289-305

[14] Sugiyono: 'Metode Penelitian Kuantitatif, Kualitatif, dan R\&D' (CV. Alfabeta, 2016. 2016)

[15] Ahmadi, A.: 'Psikologi umum' (Rineka Cipta, 2009. 2009)

[16] Shaleh, A.R.: 'Psikologi: Suatu Pengantar dalam Perspektif Islam' (Prenada Media, 2008. 2008)

[17] Morrison, G.S.: 'Pendidikan anak usia dini saat ini' (Pustaka Pelajar, 2016. 2016)

[18] Brooks, J.: 'The Process of Parenting (Revised Ed 8)' (Pustaka Pelajar, 2011. 2011)

[19] Larry, P., and Narvaez, D.: 'Handbook Pendidikan Moral dan Karakter (Handbook of Moral and Character Education)' (Nusa Media, 2014. 2014)

[20] Lestari, S.: 'Psikologi keluarga: Penanaman nilai dan penanganan konflik dalam keluarga' (Prenada Media Group, 2012. 2012)

[21] Nolte, D.L., and Harris, R.: 'Anak-anak Belajar dari Kehidupannya Nilai-nilai Parenting Klasik Dunia' (Pustaka Pelajar, 2016. 2016)

[22] Ikhsanudin, M., \& Hidayati, H. (2016). Peran Orang Tua Dalam Menanamkan Nilai Akhlak Pada Anak Di Lingkungan Keluarga. Al-I'tibar: Jurnal Pendidikan Islam, 2(1), 56-77.

[23] Dwiningrum, S.I.A.: 'Desentralisasi dan partisipasi masyarakat dalam pendidikan' (Pustaka Pelajar, 2011. 2011)

[24] Ramadhan, S., Mardapi, D., Sahabuddin, C., \& Sumiharsono, R. (2019). The estimation of standard error measurement of physics final examination at senior high schools in bima regency indonesia. Universal Journal of Educational Research, 7(7), 1590-1594.https://doi.org/10.13189/ujer.2019.070713

[25] Ramadhan, S., Nasran, S. A., Utomo, H. B., Musyadad, F., \& Ishak, S. (2019). The Implementation of generalisability theory on physics teachers' competency assessment instruments development. International Journal of Scientific and Technology Research, 8(7), 333-337. 